\title{
The Effect of E-Servicescape, Website Trust and Perceived Value on Consumer Online Booking Intentions: The Moderating Role of Online Booking Experience
}

\author{
Sally Mohamed Amer ${ }^{1}$ \\ ${ }^{1}$ Faculty of Commerce, Damietta University, New Damietta, Egypt \\ Correspondence: Sally Mohamed Amer, Lecturer of Business Administration, Faculty of Commerce, Damietta \\ University, PO box 34519, New Damietta, Egypt. E-mail: sally84@du.edu.eg
}

Received: April 12, 2021

Accepted: May 7, 2021

Online Published: May 31, 2021

doi:10.5539/ibr.v14n6p133

URL: https://doi.org/10.5539/ibr.v14n6p133

\begin{abstract}
Nowadays, there has been a rapid growth in the number of online users, which only indicates that technology is becoming even more popular. Therefore, maintaining an effective website has become essential for businesses to gain a competitive advantage. Nevertheless, the understanding of e-servicescape attributes remains unclear, especially in the tourism and hospitality sector. Therefore, this study aims to explore how the e-servicescape of a third-party website affects consumers' behavior by developing a research model. A structural equation model was utilized to test the conceptual model. The findings suggest that both aesthetic appeal and layout \& functionality can affect website trust and perceived value. Financial security affects perceived value but does not affect website trust. Both website trust and perceived value can affect online booking intentions. Furthermore, high-experienced consumers tend to have higher website trust and perceived value than less-experienced ones. Our findings provide managers with new guidance on designing and developing effective third-party websites.
\end{abstract}

Keywords: e-servicescape, third-party websites, website trust, perceived value, online booking intentions, online booking experience

\section{Introduction}

Information technology has seen exponential growth through the years, which, in turn, led to significant changes in the operations of the hospitality and tourism sector (Ho \& Lee, 2007). With the advancements in technology, the hospitality sector could now utilize a combination of online and offline channels to increase sales, improve market share, minimize costs, and increase booking levels by using third-party websites or online travel agencies (OTAs) (Toh et al., 2011). Gao and Bi (2021) defined OTAs as two-sided market consist of supply and demand sides, on the supply side, where hotel rooms benefit from new consumers introduced by OTAs, while, on the demand side, consumers benefit from search information and book hotels by using OTAs.

Innovative technologies help in creating a strong bond between different distribution channels, e.g., hotel industry companies and online travel agents, which aids in retaining consumers and increasing the hotel's market share (Tao et al., 2018).

Before the third-party websites, most consumers book their hotel via telephone, travel agents, and fax. However, with the advent of the Internet, researchers were encouraged to test the effect of Internet usage in the hospitality sector (Ip et al., 2011). Since the mid to late 2000s, hotel managers began creating their hotels' websites by providing consumers with information about the hotel via the internet where they can access information, for example, queries on room accommodations, easily and conveniently (Law, 2019). Since 2010, hotel managers have paid special attention to provide personalized customer services and developing their websites to enhance consumers' online experience, which, in turn, influences emotional responses and increases return intentions (Lee \& Jeong, 2012).

Fu Tsang et al. (2010) proposed that the number of travel websites has increased and is becoming more popular because of their ability to provide a large number of information such as price comparison and different selection of products. Furthermore, they minimize consumers' search time, provide loyalty reward programs, and ease the acquisition of options that satisfy customer needs (Toh et al., 2011). They also provide users with different values such as the followings: functional value by searching for promotional offers and comparing prices; social 
value by providing social approval and building a strong image; information value by providing all the needed information related to different offers and promotions; and preference value by providing promotional discounts and incentives before consumers book their room (Talwar et al., 2020). As a result, many travel agencies exert much effort and time for developing their websites (Yang \& Leung, 2018).

However, even though hotels prefer to sell their rooms via their websites, third-party websites remain necessary due to their ability to (i) gain a competitive advantage and (ii) offer smarter business solutions and practices related to pricing (Sánchez-Pérez et al., 2020). Hoteliers tend to use OTAs to distribute their products and services (Toh et al., 2011) as OTAs can provide effective and up-to-date technological capabilities that match the hotels' needs (Sánchez-Pérez et al., 2020). Furthermore, Anderson (2011) showed that OTAs play an integral role in increasing the online booking process of potential visitors, as $75 \%$ of consumers who intend to book rooms via a hotel's website tend to visit OTA before conducting the online booking process. OTAs' reviews represent a popular source of information that may affect consumer decisions and behaviors related to booking intentions (Chan et al., 2017).

Due to the rapid growth of the Internet and the growing numbers of website users, many studies have examined the effect of e-servicescape in online shopping (Harris \& Goode, 2010; Tankovic \& Benazic, 2018; Teng et al., 2018; Wu et al., 2018), which showed that shopping patterns in the online environment are extremely different from that of the physical stores (offline environment). Nevertheless, few studies (Huang et al., 2017; Ip et al., 2011; Law et al., 2010; Lee \& Jeong, 2012) have examined the effect of websites in the tourism and hospitality sector. Furthermore, they proposed that the e-servicescape of a third-party website is very requisite, as these websites provide consumer a preview of the hotel they are planning to visit.

Third-party websites often struggle to achieve a competitive advantage and offer consumers smarter solutions. To overcome this, a third-party website needs to attract consumers by offering an attractive website with a lot of valuable information, ease of use, usage security, and ease of payment. Yadav and Mahara (2020) suggested that there is a necessity to understand the e-servicescape environment, as there is limited empirical evidence. Furthermore, they addressed that there is a limited usage of the S-O-R framework to test the effect of e-servicescape on purchase intentions through trust in developing countries. So, this calls for an in-depth understanding of the e-sevicescape of a third-party website. To address this gap, this study has established a framework for predicting website trust and online booking intentions by adapting the framework of S-O-R to hospitality and tourism contexts.

In summary, this research contributes to a better understanding of the relationship between e-servicescape, trust toward third-party websites, perceived value, and online booking intentions by testing the proposed research model. This study assesses the effect of the moderator role of online booking experience in the relationship between e-servicescape dimensions, website trust, and the perceived value. The findings of this study extend the online booking intentions by focusing on e-servicescape in the hospitality and tourism contexts.

This paper is divided into five parts: the first is the introduction; the second demonstrates the literature review; the third discusses the research methodology; the fourth demonstrates the research results; the fifth part is the discussion and conclusion, theoretical implications, managerial implications; and, finally, the sixth part is the research limitations, and future research directions.

\section{Literature Review}

\subsection{E-servicescape}

Bitner (1992) has labeled the surrounding physical environment in the service setting as "servicescape." According to Bitner, servicescape consists of three main dimensions: ambient conditions, spatial layout/functionality, and signs/symbols and artifacts.

As a result of the development of information technology and the growing number of website users, a lot of studies have transformed their focus from the physical environment (servicescape) to the online environment, which is used in different terms such as "e-escape (Koering, 2003)," "online servicescape (Harris \& Goode, 2010; Kühn et al., 2019)," "virtual atmospherics (Abarbanel et al., 2015)," "digital servicescape (Ballantyne \& Nilsson, 2017)," and "e-servicescape" (Hopkins et al., 2009; Lai et al., 2014; Lee \& Jeong, 2012; Tankovic \& Benazic, 2018; Teng et al., 2018; Wu et al., 2018).

There has been an agreement that the concept of e-servicescape was derived from servicescape (Harris \& Goode, 2010; Tankovic \& Benazic, 2018; Teng et al., 2018; Wu et al., 2018). Nevertheless, the dimensions of servicescape differ from that of e-servicescape. The main difference between the two is associated with the 
service context. In the servicescape, consumers deal with service providers physically, whereas, in e-servicescape, the service is provided online.

The conceptualization of e-servicescape is presented by Harris \& Goode (2010); they define e-servicescape as a combination of e-environmental factors that are available during the service delivery process. They conceptualize a framework of e-servicescape by depending on the original dimensions of Bitner (1992) (ambient conditions, spatial layout/ functionality/signs, symbols, and artifacts). They used Bitner's first two dimensions and transformed them to better suit the online environment. However, the third dimension (signs, symbols, and artifacts) has been substituted with financial security, which is largely suitable to the online context.

Many studies have applied the e-servicescape dimensions of Harris and Goode in different online contexts such as online shopping (Tankovic \& Benazic, 2018; Wu et al., 2018), the hospitality and tourism sector (Huang et al., 2017), and the airline sector (Kühn et al., 2019).

Most of the previous studies agree on the important role of e-servicescape in different online contexts in encouraging consumers' emotions, opinions, beliefs, and attitudes, which, in turn, can lead to response behaviors (Tankovic \& Benazic, 2018; Wu et al., 2018). Meanwhile, Teng et al. (2018) stated that evaluating online service context is difficult, so website users can depend on e-servicescape in evaluating website attributes, which in turn forms behavioral intentions. Moreover, this research aims to study the second - order of e-servicescape to be able to determine which e-servicescape dimension is the best antecedent of website trust and perceived value.

\subsection{Trust Toward Third-Party Website}

Nowadays, electronic businesses have become an important phenomenon as it fosters a lot of companies to design an attractive and trustworthy website. The Internet environment remains to be unsafe and risky; thus, trust-building becomes an important tool to encourage customer to use the company's website (Jafarpour \& Andalib, 2016). E-trust refers to customer's subjective belief that the organization will fulfill all transactional obligations as the customer expects (Kim et al., 2008).

Harris and Goode (2010) asserted that trustworthiness is one of the most valuable factors that customers tend to evaluate when dealing with an e-service. Consequently, numerous studies have examined the effect and the importance of trust in the online service e.g. (Agag and El-Masry 2016a; Agag and El-Masry 2016b; Agag et al. 2019; Al-dweeri et al. 2017; Jafarpour and Andalib 2016), concluding that increasing customers' trust is necessary for any online service setting to achieve success. Baki (2020) showed that trust plays an important role in building strong relationships between sellers and buyers.

After reviewing the previous studies, there has been an increasing interest among academics to explore the integral effect of e-trust in online service settings and its antecedents (Agag et al., 2019; Harris \& Goode, 2010; Jafarpour \& Andalib, 2016; Kühn et al., 2019). Harris and Goode (2010); Wu et al. (2018) suggested that when a website design is attractive, thus helping in achieving service goals that can develop trust toward the website; meanwhile, perceived security also has a great effect in increasing consumers' trust. Furthermore, Tatar and Eren-Erdoğmuş (2016) stated that having a clear, secure website and online interactivity can increase website trust. Andriani et al. (2021) showed that e-servicescape is an antecedent of trust and this happens when e-servicescape successes in satisfying consumer desires. Furthermore, Kurniawati and Yaakop (2021) suggested that encouraging trust through e-servicescape considers one of the most effective ways for e-commerce vendors in retaining existing customers and attracting new customers.

Therefore, understanding the role of e-servicescape and how it increases consumers' trust is vital in the tourism sector. Therefore, the following hypotheses were formulated as follows:

H1: E-servicescape dimensions (H1a) aesthetic appeal, (H1b) layout \& functionality, and (H1c) financial security will positively affect trust toward a third-party website.

\subsection{Perceived Value}

Providing consumers with a valuable exchange based on comparing benefits and costs of a product or a service is necessary both offline and online (Tankovic \& Benazic, 2018). According to Nilsson and Ballantyne (2014), servicescape can improve consumers' perception of value, thus influencing service expectations.

The results of Tankovic and Benazic (2018), support that e-servicescape dimensions (layout and functionality and financial security) have been determined to influence consumers' perception of value. However, the aesthetic appeal does not affect perceived value. So, they suggest that there is a necessity to explore the effect of the second- order of e-servicescape on the perceived value. Therefore, the following hypotheses were formulated as follows: 
H2: E-servicescape dimensions (H2a) aesthetic appeal, (H2b) layout \& functionality, and (H2c) financial security will positively affect perceived value.

\subsection{Trust Toward a Third-Party Website and Hotel's Booking Intentions}

Nowadays, consumers are increasingly booking hotels online. To be able to understand online booking intentions, we utilized the theory of reasoned action (TRA), which proposed that consumers' attitude toward a stimulus results from a consumer's belief or cognitive evaluation of the stimulus. TRA states that a consumer's intention to make an action is an important antecedent of actual behavior (Fishbein, 1979). Rauyruen et al. (2009) suggested that trust is considered as the link between the transactions happening before the actual purchase and after the purchase process, which then leads to purchase intentions. Due to the difficulty of measuring actual behaviors, this paper measures behavioral intentions as the superior predictors of consumers' actual behaviors.

Kim et al. (2017) proposed that consumers are skeptical about online booking; thus, they require all the necessary information before booking a room. To decrease consumer suspicion, hotels need to design a trustworthy website that matches consumers' expectations. Furthermore, Li et al. (2017) suggested that trust toward the website enhances the online purchasing intentions, as they showed that the online purchase intention in the case of the hotels is represented by online booking intentions. Baki (2020) addressed that consumer with a high level of trust toward the website is more likely to make a purchase. So, the following hypothesis was constructed:

H3: Trust toward third-party websites has a positive impact on the consumers' intentions to book a hotel online.

\subsection{Perceived Value and Hotel's Online Booking Intentions}

Consumers' perceived value has been identified as the core element in the purchase intention; it is the perception of the benefits and the costs of the consumer products at the repurchase process (Shafiq et al., 2011). Malik and Rao (2019) stated that perceived value means meeting consumers' expectations.

Previous studies have paid much interest to the effect of perceived value on user behavior in different commercial contexts. In an offline context, Boksberger and Melsen (2011) proposed that perceived value is vital in-service organizations, as it helps them provide a good service that matches consumers' needs and wants, thus affecting the consumers' purchase intentions.

Shafiq et al. (2011) confirmed that the consumer's perceived value of consumer products affects purchase intentions. In the online shopping context, Tankovic and Benazic (2018); Wu and Chang (2016) stated that perceived value can positively influence online purchase intentions. Meanwhile, in the tourism sector, Agag et al (2019); Chang et al. (2014); Kim et al. (2017); Ponte et al. (2015) suggested that the consumer's perception of value has a positive effect on purchase intentions.

According to Kahneman and Tversky's (1979) theory, we propose that the overall assessment of a product or service benefits and costs can affect consumer's intention to purchase online. Thus, the following hypothesis was formulated:

H4: Perceived value has a positive effect on the consumers' intentions to book a hotel online.

\subsection{The Moderator Role of Online Booking Experience}

Prior studies Ling et al. (2010); Wu et al. (2018) stated that customers evaluate their online purchase experiences according to their perceptions of visual appeal, privacy, personalization, product information, and entertainment. So, the availability of a company's information can significantly help in formulating customer's previous purchase experience. Less experienced customers tend to be more risk-averse than those who are highly experienced (Lee \& Tan, 2003). Wu et al. (2018) suggested that high-experienced customers tend to have higher website trust than less-experienced customers. So, the following hypothesis was constructed as follows:

H5: The effect of e-servicescape dimensions on trust toward the website will be higher for high-experience consumers than low-experience cconsumerss.

Koyuncu and Lien (2003) suggested that high-experienced customers have lower risks than less-experienced customers. Soopramanien (2011) argued that high-experienced customers tend to have a higher ability to evaluate the benefits and costs of products and are less skeptical about online shopping. The study showed that online experience plays an integral role in influencing how customers evaluate the benefits and risks related to the use of online shopping. Therefore, the following hypothesis was constructed:

H6: The effect of e-servicescape dimensions on perceived value will be higher for high-experienced consumers than low-experienced consumers. 
Depending on the literature review, we develop the research framework (Figure1).

\subsection{Theoretical Background}

Basin on the literature review, we develop the research framework (Figure1). In this research, we adopt the stimulus-organism-response (S-O-R) framework of Mehrabian \& Russell (1974). This framework was the first to investigate the effect of the environment on consumer behavior. Furthermore, S-O-R introduced a theoretical background for the e-servicescape effects (Wu et al., 2018). Previous studies (Bitner,1992; Choi and Kandampully, 2019; Pizam and Tasci, 2019) have widely used the S-O-R model to examine the effect of servicescape on consumers' cognitions, emotions, and expectations.

Meanwhile, most of the previous studies (Harris and Goode, 2010; Tankovic and Benazic, 2018; Teng et al., 2018; Wu et al., 2018) showed that the e-servicescape concept was derived from the servicescape concept; thus, this study depended on the S-O-R model. The stimulus (S) represents the variables that affect the organism (O) and consumer's emotions, opinions, emotions, beliefs, and attitudes, which, in turn, lead to the approach or avoidance response $(\mathrm{R})$ behaviors. In this research, the stimulus is the e-servicescape (S), consumers' trust toward the website, and perceived value represent the organism (O), which leads to hotels' online booking, which represents the response $(\mathrm{R})$.

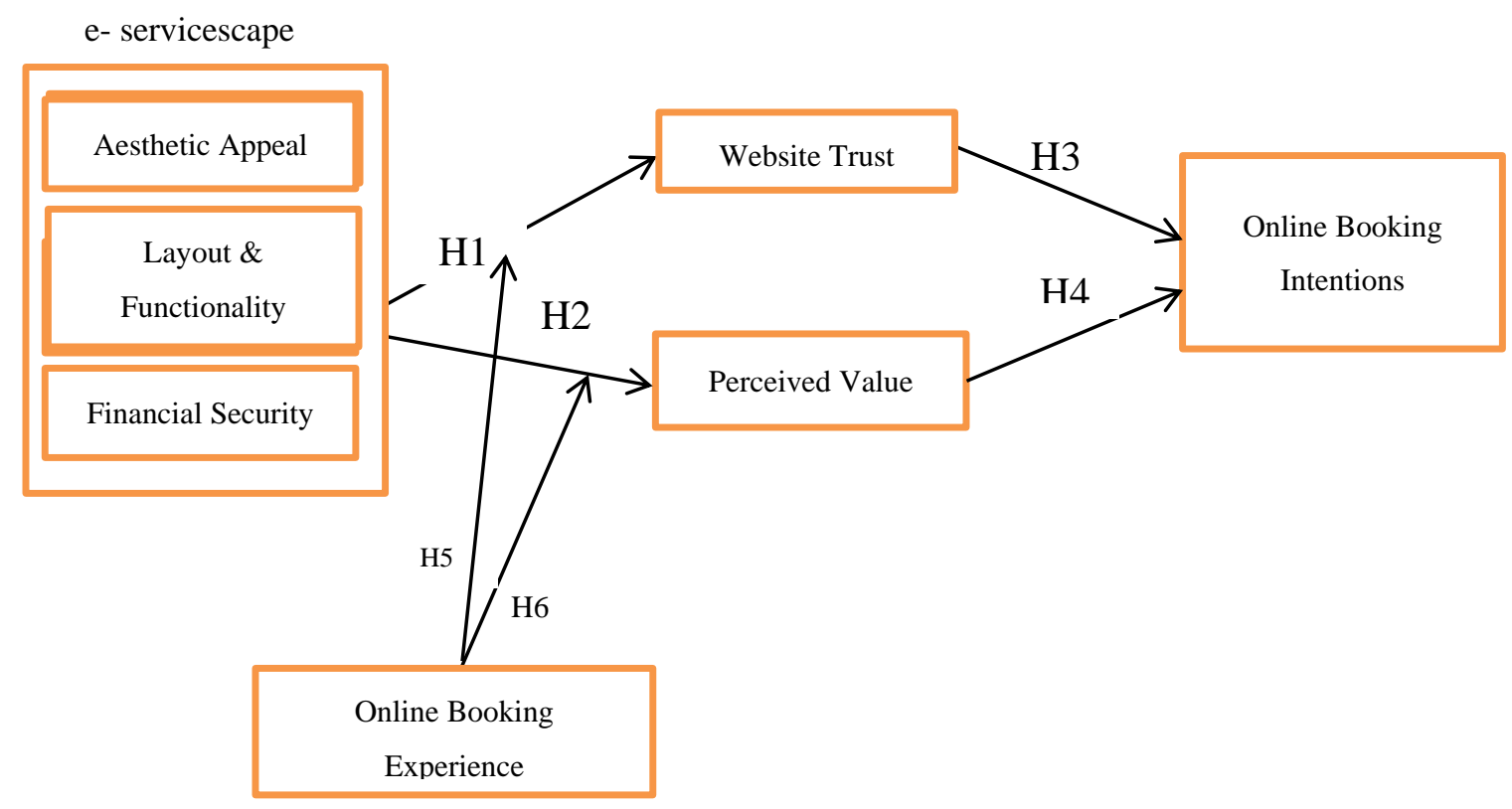

Figure 1. The research framework

\section{Research Methodology}

This research used a questionnaire to collect data from consumers who book a hotel via third-party websites. The following sections cover the sampling procedures, data collection process, questionnaire design, and its measures.

\subsection{Sampling and Data Collection Process}

We applied a positivism philosophy and quantitative methods, which are more suitable for collecting data via questionnaire and understanding the factors that impact the hotel's online booking. The study population involved all the hotel consumers. The sample consists of travelers who have at least made one online booking via a third-party website in the last 2 years. Respondents were then asked to choose the website, which they are familiar with, their favorite website, and the one they frequently use.

In Egypt, it is impossible to make a direct selection of a sample from the population, as there is no list of consumers' names who actually book hotel online via third-party websites in the last 2 years. So, convenience sampling (non-random sampling) has been determined as the most suitable technique to collect data where the members of the target population have met certain criteria e.g., geographical proximity, easy accessibility to the researcher, and willingness to participate (Etikan, 2016). 
The constructs were measured using Google Forms, and the questionnaire's link was posted on Facebook. Google Form application was chosen for several reasons; first, it is useful when the sample is largely demographically diverse. Second, hotel consumers in Egypt are widespread. Third, there is no list of consumers' names who book hotel online via third-party websites, so it is difficult to make a direct selection of a sample from the population. To ensure a consistent framework of the sample, respondents were asked to answer a screening question in the first section to verify eligibility, that is, respondents were asked if they made an online booking using third-party websites in the last 2 years. Positive answers enabled respondents to continue with the questionnaire.

The sampling method began as a convenience sample, which developed into snowball sampling as more respondents recommended other participants. The time needed to complete the survey is approximately 10-15 min. Thus, 324 participants answered the questionnaire (response rate $=81 \%$ ); 298 of them were valid and free of missing data, while 18 of them failed to pass the screening question, and 8 were invalid.

According to Jackson (2003), the minimum sample size should be a ratio of cases $(\mathrm{N})$ to the required estimated parameters (q), and the ratio of estimation parameters to sample should be 1:10. This rule is suitable for the maximum likelihood (ML) method, which is by far the most prevalent method used in structural equation modeling (SEM) (Kline, 2011). According to this equation, our study sample size of responses fulfills the lower sample size criterion for implementing SEM. Table 1 shows the demographic characteristics of respondents.

Table 1. Demographic characteristics of respondents

\begin{tabular}{cccc}
\hline Variable & Category & $\mathrm{N}$ & $\%$ \\
\hline \multirow{2}{*}{ Gender } & Male & 120 & 40.3 \\
& Female & 178 & 59.7 \\
\hline & $18-29$ & & \\
& $30-39$ & 138 & 49.2 \\
Age & $40-49$ & 59 & 19.8 \\
& $50-59$ & 6 & 2 \\
& Over 60 & 8 & 2.7 \\
\hline \multirow{2}{*}{ Educational level } & Not graduated from the university & 2 & 0.7 \\
& Bachelor's degree & 194 & 65.1 \\
& Master's or PhD & 102 & 34.2 \\
\hline & Less than 3000 L.E & 23 & 7.7 \\
Income & 3000 L.E less than 6000 L.E & 80 & 26.8 \\
& 6000 L.E to less than 9000 L.E & 93 & 31.2 \\
Note: $\mathrm{n}=298$ & Over 9000 L.E & 102 & 34.2 \\
\hline
\end{tabular}

Respondents are familiar with different third-party websites such as Agoda, AlMosafer, Wego, Trivago, TripAdvisor, and Expedia. Table 2 shows consumer's opinions related to third-party websites.

Table 2. Consumer's opinions related to a third-party website

\begin{tabular}{ccc}
\hline Third-party websites & Favorite website & $\begin{array}{c}\text { The website that they } \\
\text { frequently use }\end{array}$ \\
\hline Booking & 183 & 191 \\
\hline Hotels & 49 & 47 \\
\hline Agoda & 12 & 11 \\
\hline AlMosafer & 6 & 5 \\
\hline Wego & 7 & 8 \\
\hline Trivago & 16 & 6 \\
\hline TripAdvisor & 11 & 13 \\
\hline Other websites & 14 &
\end{tabular}




\subsection{Study Context}

This study is applied to Egypt for several reasons; first, Egypt is considered one of the most important tourism destinations in the world. Second, tourism is considered as one of the main sources of the Egyptian economy and foreign currency (Elbaz et al., 2018). Third, Egypt has been known to be one of the main leaders in the usage of the Internet and technology in the Middle East. Fourth, Egyptian consumers represent a necessary segment that hasn't received much attention in previous consumer behaviors. Fifth, most of the previous studies have been conducted in developed countries, and the application of e-commerce transactions in developing countries has remained to be scarce (Agag et al., 2019). Finally, it is important to determine the antecedent of consumers' e-trust and perceived value related to third-party websites to improve the Egyptian tourism sector.

\subsection{Questionnaire Design and Its Measures}

The final questionnaire consists of two parts. The first part was designed to examine the study constructs (e-servicescape, website trust, perceived value, online booking intentions, and online booking experience). To measure the construct items, a five-point Likert scale was used, ranging from strongly disagree (1) to strongly agree (5). This research deals with e-servicescape as a second-order factor that consists of aesthetic appeal, layout \& functionality, and financial security.

For the first part, e-servicescape was measured by the shortened scale of Harris and Goode (2010) through 24 items. The e-servicescape construct was as follows: aesthetic appeal (6 items); layout \& functionality (13 items); and financial security ( 5 items). Trust toward a third-party website was measured by four items adapted from (Kim et al., 2011 and Wang et al., 2015). Perceived value was measured through four items copied from (Kim et al., 2012 and Ponte et al., 2015). The booking intentions construct was measured through three items adapted from (Kim et al., 2012). The previous online booking experience was then adapted to match the hotel context, which was measured by three items adapted from (Dai, 2007, and the researcher). The second part represents the respondents' demographic variables (gender, age, education level, and income level).

\section{Results}

Hoyle (1995) stated that structural equation modeling (SEM) is a comprehensive statistical approach for testing hypotheses about relations among observed and latent variables. SEM was used to test the causal relationships that are represented by a series of structural relations (Byrne, 2013). It is a very useful technique to examine the direct and indirect relationship between variables. It can also minimize measurement errors (Civelek, 2018).

In SEM, two main steps were conducted to assess the proposed model. First, the measurement model was evaluated to assess the reliability and validity of the study variables. Second, the structural model was conducted to assess the model fit and testing the hypothesis (Anderson \& Gerbing, 1988). The maximum likelihood estimation was then conducted to determine the measurement and structural model.

\subsection{Measurement Model}

Significantly, to test the adequacy of the sample size, the Kaiser-Meyer-Olkin (KMO) measure of sampling adequacy was used in this study. The findings addressed that the value of KMO was above 0.80 , which supports the use of factor analysis, and the data can then be grouped into a smaller set of factors, suggesting sampling adequacy. Furthermore, the researcher also tests the multicollinearity to ensure that there is no serious problem that resulted from the increased overlapping between the independent variables. We then estimated the variable inflation factor (VIF) for each model run. The results showed that all VIF values do not exceed 3, and the tolerance value was around $>0.2$, so there is no multicollinearity problem ( $\mathrm{O}^{\prime}$ brien, 2007). Moreover, for evaluating the measurement model, we conducted reliability and validity tests.

For improving the model fit of the measurement model, we deleted some items, so eleven items of e-servicescape and two items of perceived value were deleted (see "Appendix A").

This study applied AMOS (V. 23) to analyze the measurement model. The maximum likelihood estimation was conducted. Fit indices for the measurement model $(\mathrm{x} 2=2.048$, comparative fit indices $(\mathrm{CFI})=0.933$, and the root mean square error of approximation (RMSEA) $=0.059$ falls within the acceptable range of 0.05 to 0.08 (Hair et al., 2014). Overall, the model had acceptable goodness of fit.

The reliability, convergent validity, and discriminant validity were then examined before testing the hypotheses. As shown in Table 3, the reliability of all constructs was above 0.7 (Hair et al., 2014). Besides, the factor loading for each construct was between 0.359 and 0.884 , which is higher than the suggested rule that factor loading for each item should be $\geq 0.35$ when the sample exceeds 250 units, as the sample size $=298$ (Hair et al., 2014). 
Composite reliability (CR) values ranged from 0.678 to 0.874 , which is above 0.6 . The average variance extracted (AVE) values for all constructs were determined to be above 0.5, except for aesthetic appeal and financial security (Fornell \& Larcker, 1981). The AVE of aesthetic appeal is equal to 0.452, whereas the financial security construct is equal to 0.435 . Further, Malhotra and Dash (2016) suggested that reliability can be established through CR alone, as AVE is often too strict. So, convergent validity has been confirmed.

Table 3. The results of the measurement model of the study's variables

\begin{tabular}{|c|c|c|c|c|}
\hline Construct/Indicators & Loadings & $\begin{array}{l}\text { Composite } \\
\text { Reliability } \\
\quad \text { (CR) }\end{array}$ & $\begin{array}{c}\text { Cronbach's } \\
\text { alpha }\end{array}$ & $\begin{array}{c}\text { Average } \\
\text { Variance } \\
\text { Extracted } \\
\text { (AVE) }\end{array}$ \\
\hline Online booking intentions & & 0.854 & 0.840 & 0.665 \\
\hline $\begin{array}{l}\text { My willingness to book hotel rooms from this website is } \\
\text { high }\end{array}$ & 0.884 & & & \\
\hline $\begin{array}{l}\text { If I were to book hotel rooms, I would consider booking it } \\
\text { from this website }\end{array}$ & 0.874 & & & \\
\hline I expect to book hotel rooms online in the near future & 0.670 & & & \\
\hline Trust toward third-party website & & 0.852 & 0.865 & 0.592 \\
\hline I believe that this website is trustworthy & 0.661 & & & \\
\hline This website has integrity & 0.766 & & & \\
\hline The website fulfills its promise & 0.856 & & & \\
\hline The website provides reliable information & 0.782 & & & \\
\hline Perceived Value & & 0.743 & 0.720 & 0.593 \\
\hline $\begin{array}{l}\text { Considering the money, I pay to book the hotel on this } \\
\text { website, online booking here is a good deal }\end{array}$ & 0.702 & & & \\
\hline $\begin{array}{l}\text { Considering the effort, I make in booking on this website, } \\
\text { online booking here is worthwhile }\end{array}$ & 0.833 & & & \\
\hline Atheistic Appeal & & 0.765 & 0.794 & 0.452 \\
\hline The way it displays its products is attractive & 0.552 & & & \\
\hline Is conservative & 0.776 & & & \\
\hline I think that this web site is very entertaining & 0.701 & & & \\
\hline The enthusiasm of this web site is catching, it picks me up & 0.641 & & & \\
\hline Layout \& Functionality & & 0.860 & 0.854 & 0.508 \\
\hline $\begin{array}{l}\text { There are convenient ways to maneuver among related } \\
\text { pages and between different sections }\end{array}$ & 0.706 & & & \\
\hline Navigation through this web site is intuitively logical & 0.776 & & & \\
\hline This web site is user-friendly & 0.804 & & & \\
\hline Technical details about products can be easily accessed & 0.712 & & & \\
\hline This web site is tailored toward me & 0.674 & & & \\
\hline $\begin{array}{l}\text { This web site makes purchase recommendations that } \\
\text { match my needs }\end{array}$ & 0.582 & & & \\
\hline Financial security & & 0.678 & 0.642 & 0.435 \\
\hline Payment procedures seem to take a long time & 0.704 & & & \\
\hline Paying for goods involves entering a lot of details & 0.825 & & & \\
\hline $\begin{array}{l}\text { When buying from this web site I am not reassured by the } \\
\text { security procedures }\end{array}$ & 0.359 & & & \\
\hline Online booking experience & & 0.874 & 0.867 & 0.698 \\
\hline I booked hotels via a third-party website for a long time & 0.846 & & & \\
\hline I frequently book hotels via a third-party website & 0.872 & & & \\
\hline I have good information related to the booking process & 0.786 & & & \\
\hline
\end{tabular}

Discriminant validity is accepted if each construct's AVE is larger than its shared variance with any other construct. In Table 4, the square root of AVE of each construct is proved to be larger than the correlations among the constructs (Fornell \& Larcker, 1981), which is realized for all constructs. 
Table 4. Discriminant validity for the study's construct

\begin{tabular}{|c|c|c|c|c|c|c|c|}
\hline $\begin{array}{c}\text { Study's } \\
\text { dimensions }\end{array}$ & $\begin{array}{c}\text { Aesthetic } \\
\text { Appeal }\end{array}$ & $\begin{array}{c}\text { Layout\& } \\
\text { Functionalty }\end{array}$ & $\begin{array}{c}\text { Website } \\
\text { Trust }\end{array}$ & $\begin{array}{c}\text { Online } \\
\text { booking } \\
\text { intentions }\end{array}$ & $\begin{array}{c}\text { Online } \\
\text { booking } \\
\text { experience }\end{array}$ & $\begin{array}{l}\text { Perceived } \\
\text { value }\end{array}$ & $\begin{array}{c}\text { Financial } \\
\text { security }\end{array}$ \\
\hline $\begin{array}{l}\text { Aesthetic } \\
\text { Appeal }\end{array}$ & 0.673 & & & & & & \\
\hline $\begin{array}{c}\text { Layout\& } \\
\text { Functionality }\end{array}$ & 0.578 & 0.713 & & & & & \\
\hline Website Trust & 0.481 & 0.701 & 0.769 & & & & \\
\hline $\begin{array}{l}\text { Online booking } \\
\text { intentions }\end{array}$ & 0.531 & 0.680 & 0.723 & 0.815 & & & \\
\hline $\begin{array}{c}\text { Online booking } \\
\text { experience }\end{array}$ & 0.449 & 0.568 & 0.557 & 0.667 & 0.835 & & \\
\hline Perceived value & 0.529 & 0.509 & 0.641 & 0.754 & 0.573 & 0.770 & \\
\hline $\begin{array}{l}\text { Financial } \\
\text { security }\end{array}$ & 0.259 & 0.279 & 0.207 & 0.382 & 0.381 & 0.376 & 0.660 \\
\hline
\end{tabular}

Note: AVE's square roots are shown on diagonal.

$* \mathrm{P}$ value $<0.001$

After validating the measurement model, the researcher will advance to the next required step, "structural model assessment."

\subsection{Data Analysis: Structural Model Assessment}

The structural model assessment describes the causal relationships between latent variables, and it aims to test the hypothesized research model. The results of the structural model confirmed that overall, the model had acceptable goodness of fit of Hair et al. (2014) $(\mathrm{x} 2=2.519$, comparative fit indices (CFI) $=0.906$ and the root mean square error of approximation $($ RMSEA) $=0.072$. The results of testing hypotheses from H1 to H4 (See Figure 2). Table 5 shows the $\beta$, the p-values, and the decision related to the hypotheses.

Table 5. The results of structural model and hypotheses testing

\begin{tabular}{|c|c|c|c|c|c|}
\hline Hypotheses & Independent Variable & Dependent Variable & $\beta$ & P-value & Decision \\
\hline $\mathrm{H} 1 \mathrm{a}$ & Aesthetic appeal & \multirow{3}{*}{ Trust toward third party website } & 0.138 & ** & Accepted \\
\hline $\mathrm{H} 1 \mathrm{~b}$ & Layout \& Functionality & & 0.531 & $* * *$ & Accepted \\
\hline H1c & Financial security & & 0.072 & 0.124 & Rejected \\
\hline $\mathrm{H} 2 \mathrm{a}$ & Aesthetic appeal & \multirow{3}{*}{ Perceive value } & 0.237 & $* * *$ & Accepted \\
\hline $\mathrm{H} 2 \mathrm{~b}$ & Layout \& Functionality & & 0.227 & $* * *$ & Accepted \\
\hline $\mathrm{H} 2 \mathrm{c}$ & Financial security & & 0.171 & $* * *$ & Accepted \\
\hline $\mathrm{H} 3$ & $\begin{array}{c}\text { Trust toward third-party } \\
\text { website }\end{array}$ & \multirow{2}{*}{ Online booking intentions } & 0.410 & $* * *$ & Accepted \\
\hline $\mathrm{H} 4$ & Perceived value & & 0.385 & $* * *$ & Accepted \\
\hline
\end{tabular}

Note: $* * \mathrm{p}<0.01, * * * \mathrm{p}<0.001$

Figure 2 shows the influences of aesthetic appeal $(\beta=0.138 ; p<0.01)$ and layout\& functionality $(\beta=0.531 ; p<$ 0.001 ) on trust toward third-party websites are significant. Therefore, hypotheses H1a and H1b are acceptable. However, the interrelationship between financial security and trust toward a third-party website was found to be insignificant $(\beta=0.072 ; p=0.124)$, so H1c was then rejected. Similarly, aesthetic appeal $(\beta=0.237 ; p<0.001)$, layout\& functionality $(\beta=0.227 ; \mathrm{p}<0.001)$, and financial security $(\beta=0.171 ; \mathrm{p}<0.001)$ on perceived value were determined significant. So, $\mathrm{H} 2 \mathrm{a}, \mathrm{H} 2 \mathrm{~b}$, and $\mathrm{H} 2 \mathrm{c}$ are supported. Moreover, $\mathrm{H} 3$ predicted that trust toward a third-party website has a positive impact on online booking intentions $(\beta=0.410 ; p<0.001)$. Moreover, H4 addressed that perceived value has a positive effect on consumer's intentions to book a hotel online $(\beta=0.385 ; \mathrm{p}$ $<0.001$ ), and Figure 2 confirms. 


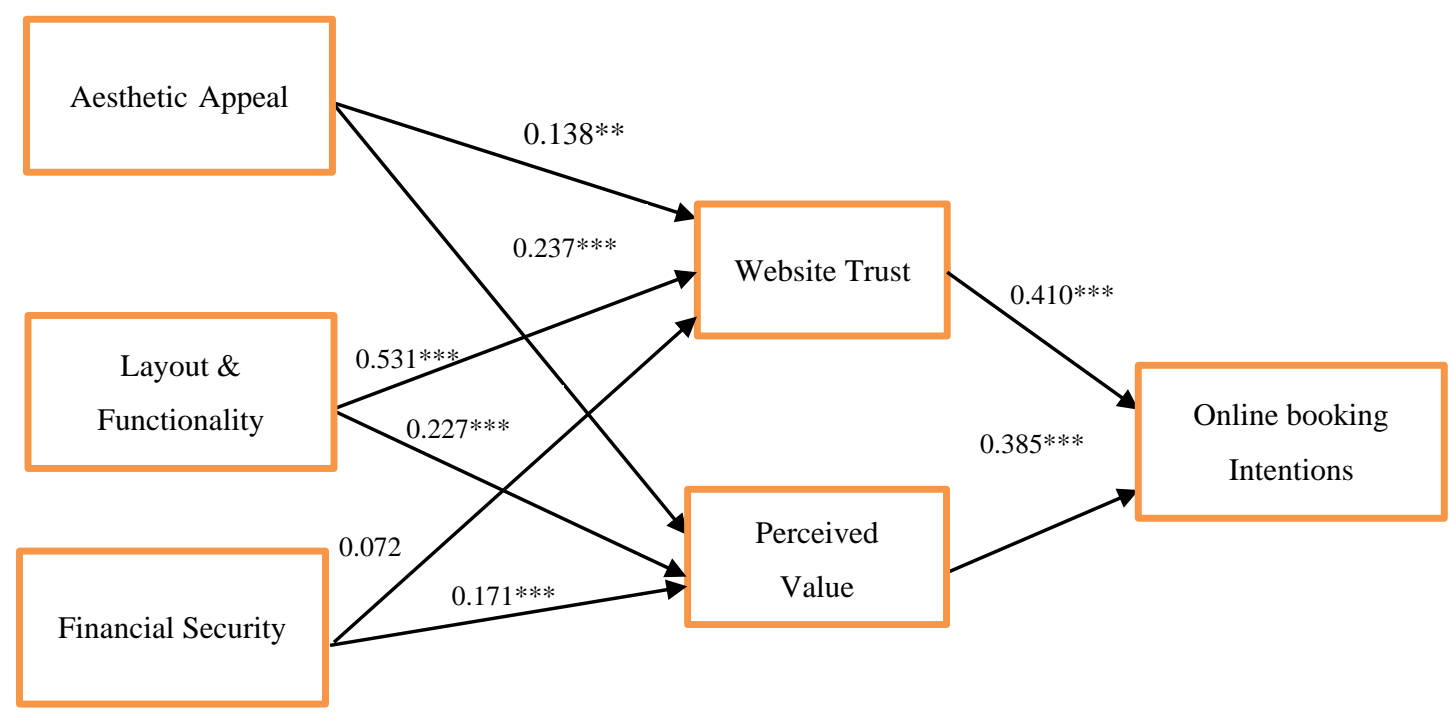

Figure 2. The results of hypotheses testing

For exploring the moderating role of online booking experience on the relationship among e-servicescape, trust toward the third-party website, and perceived value. We divide the respondents into four groups by using the K-means cluster technique. For example, the four groups for financial security and online booking experience are (1) High financial/ high online booking experience; (2) High financial/ low online booking experience; (3) low financial/ high online booking experience; and (4) low financial/ low online booking experience.

As shown in Figure 3, the findings show that consumers with higher experience tend to have a higher level of trust toward third-party websites in terms of aesthetic appeal $(\mathrm{F}=52.763 ; \mathrm{p}<0.001)$. Therefore, H5a is supported. Also, higher-experienced consumers have a higher level of trust in websites than less-experienced ones toward layout\& functionality $(\mathrm{F}=26.653 ; \mathrm{p}<0.001)$. So, H5b is acceptable. Respondents with high experience also have higher trust toward third-party websites in relation to financial security $(\mathrm{F}=213.777$; $\mathrm{p}<$ 0.001). So, H5c is supported.

Similarly, respondents with higher experience also have a higher level of perceived value toward aesthetic appeal rather than the less-experienced ones $(F=40.988$; $p<0.001)$. So, H6a is supported. Moreover, more experienced consumers tend to have higher perceived value than less-experienced ones in terms of layout\& functionality $(\mathrm{F}=26.913 ; \mathrm{p}<0.001)$. So, H6b is accepted. Respondents with higher experience were also found to have a higher level of perceived value in relation to financial security $(F=225.209 ; \mathrm{p}<0.001)$. So, H6c is accepted, and so $\mathrm{H} 5$ and $\mathrm{H} 6$ are supported (Figure 3). 

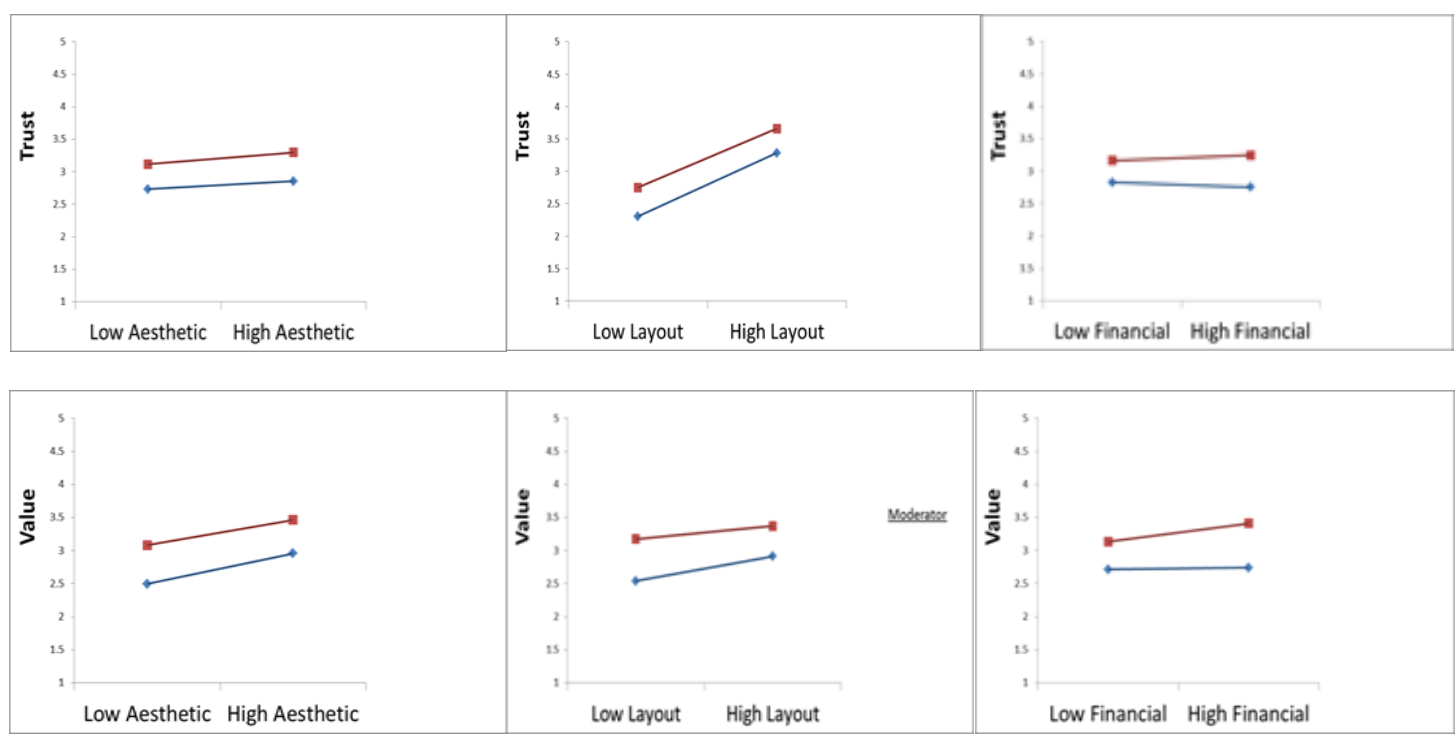

Note: $\longleftrightarrow$ = high online booking experience

$\rightleftarrows=$ low online booking experience

Figure 3. The role of the moderator variable (online booking experience)

\section{Discussion and Implications}

\subsection{Conclusion}

Depending on the S-O-R model, we applied e-servicescape to the hospitality and tourism sector. We explored whether the dimensions of e-servicescape can lead to online booking intentions through website trust and perceived value.

First, we found some agreement upon the generalization of Harris and Goode's model of e-servicescape, and especially in aesthetic appeal and layout \& functionality. In this regard, this study suggests that both aesthetic appeal and layout \& functionality play an important role in enhancing consumer trust. The study's findings did not find a relationship between financial security and trust toward a third-party website, but this insignificant result may be due to the Egyptian consumers' nature, as they are more skeptical about the security policies and procedures in the e-service context. This is matched with Jafarpour and Andalib (2016), as they recognized that the internet environment is unsafe and risky, so trust-building becomes an important tool to encourage customers to deal with the company's website. Moreover, Harris and Goode (2010) proposed that there is the weakest link between financial security and trust toward the website. Therefore, the third-party website should exert much effort in securing consumers' personal and payment method data. They should clarify to their consumers, how websites secure their information.

Second, our results confirm that the three dimensions of e-servicescape have a significant effect on the consumer's perception of value. These results contradict Tankovic and Benazic (2018) that aesthetic appeal does not affect perceived value. However, they agree that layout \& functionality, and financial security influence customers' perception of value. When consumers feel that the e-servicescape of a third-party website concentrates on aesthetics, arrangement and structure, usability, information relevance, site security, fair prices, and saving time and effort, this increases their perception of value.

Third, consumers are more likely to book hotels when they trust the third-party website. Our findings are consistent with various studies, which demonstrated that trust in a website has a positive impact on booking intentions (Kim et al., 2017; Li et al., 2017). This may be due to the consumer's need to collect all the needed information to trust the hotel.

Fourth, consumers are more likely to book hotels when they perceive the value of the website. Our findings are also consistent with that of Agag et al. (2019); Chang et al. (2014); Kim et al. (2017); Ponte et al. (2015), who showed that consumers' perception of value has a positive effect on booking intentions. This is also in line with 
Kahneman and Tversky's (1979) theory, which assumes that the overall assessment of a product or service's benefits and costs affect online purchase intention.

Fifth, more online booking experience enhances trust toward websites. Our findings agree with Wu et al. (2018) who argued that high-experienced customers have higher website trust than less-experienced ones. So, when consumers can evaluate their online booking experience related to their perceptions of visual appeal, the relevance of information, and entertainment, this will increase trust.

Finally, more online booking experience improves the consumer's perception of value. Our findings are in line with Koyuncu and Lien (2003); Soopramanien (2011) who argued that high-experienced customers have a higher ability to assess the benefits and costs of products. So, these consumers can better evaluate booking processes via third-party websites.

\subsection{Theoretical Implications}

Using the S-O-R model, this paper helps in understanding how the construct of e-servicescape at hotels and the tourism sector is affecting website trust, perceived value, and booking intentions. This paper also contributes by filling research gaps in the following points:

First, a shortened version of Harris and Goode's (2010) e-servicescape scale is applied for testing the effect on website trust and the perceived value and booking intention by utilizing the S-O-R model. Many studies focusing on e-servicescape in the online shopping context few examine it in the hospitality context.

Second, this research deals with e-servicescape as a second-order factor, exploring its impact on website trust and consumers' perception of value. This matched with the recommendation of Tankovic and Benazic (2018) to study the impact of each dimension of e-servicescape separately on the customers' perception of value.

Third, this research advances the literature by exploring how website trust and perceived value affect online booking intention. Prior literature did not give much attention in examining the effect of e-servicescape on perceived value and trust toward third-party websites in the tourism sector through the S-O-R framework.

Fourth, this research contributes to the literature by studying the moderating role of the online booking experience in the tourism sector. Prior studies gave much attention to examine the effect of the online experience in the online purchasing context few examine it in the hospitality context.

\subsection{Managerial Implications}

Managers who are responsible for designing a third-party website should consider the aesthetic appeal and layout $\&$ functionality and combine them to enhance trust. However, our findings argued that there is no significant effect of financial security on website trust. Managers and designers should work more on the security policies by showing how the website secures all personal and financial information against fraud and theft and further provide privacy guarantees to increase trust.

To enhance website trust and perceived value, third-party websites should exert more effort to enhance the visual appeal, aesthetics, and entertainment value of websites. Designers should concentrate on improving the aesthetic appeal as it constitutes first impression (Tankovic \& Benazic, 2018). Special focus should be put on functionality $\&$ layout as they are considered as important criteria for evaluating online content. Managers should focus on increasing the websites' usability, managing all the needed information, and personalizing parts of their website pages to meet customer needs and wants. Moreover, the research showed that financial security has a positive effect on website perceived value. Therefore, special focus should be put on providing policies and procedures that ensure transaction security to protect consumers' personal and financial data, showing how the payment processes are safe and secure.

Alternatively, research indicates the existence of the positive effects of website trust, perceived value, and booking intention via third-party websites; marketing managers and designers should make the necessary steps to enhance website trust and perceived value. As per our findings, managers should encourage consumers to post their reviews, showing the benefits and costs they have incurred when using this third-party website and how the use of this website has saved consumers' time, money, and effort. In this way, the perceived risk and uncertainty in terms of using the website will decrease. Managers should enable consumers to rate the privacy and security levels of the website and how it secures their personal and financial data. All these procedures will help in increasing trust. Furthermore, managers should provide 24/7 service for answering consumers' inquiries to motivate consumers to continue booking through their websites. This direct contact with consumers will help managers to know what prevents consumers from booking online and thus try to solve all these problems which may help in increasing the website trust and perceived value. 
Managers should seek to attract less-experienced consumers and try to increase their website trust level by providing them with all the needed information.

Moreover, high experienced customers tend to have a higher ability to evaluate the benefits and the costs of the product and have a lower risk than low-experienced customers (Soopramanien, 2011). Managers should seek to attract low experienced ones by providing various promotional offers and encouraging consumers to participate in loyalty programs and showing how consumers who frequently book hotels via third-party websites will benefit from offers and save money. These mechanisms, managers can be used to encourage consumers to frequently book hotels via the third-party website.

Finally, consumers' perception of website trust and perceived value were found to be higher in high-experience consumers than in low consumers. A high-experienced consumer seems to be more knowledgeable and able to evaluate their online booking experiences according to their perceptions of visual appeal, privacy, personalization, product information, and entertainment. Thus, high-experienced customers tend to have higher website trust (Wu et al., 2018), while less-experienced customers tend to be more risk-averse (Lee \& Tan, 2003). Managers should seek to attract less-experienced consumers and try to increase their website trust level by providing them with all the needed information.

Additionally, high-experienced customers tend to have higher perceived value (Soopramanien, 2011). Managers should seek to attract low experienced ones by providing various promotional offers, encouraging participation in loyalty programs, and showing how consumers who frequently book hotels via the website will benefit from offers and save money.

\section{Limitations and Future Research Directions}

This study has some limitations. First, the study's sample was drawn from Egypt's population, so generalizing the results may be difficult. Future studies should incorporate other countries and perform a comparative study between developed and developing countries to understand the moderating role of culture. Second, this study tested the hypotheses with a questionnaire that provided only cross-sectional data. Future research can develop a longitudinal study to address methodological limitations. Third, future studies can explore the relationship between e-servicescape and other important variables, such as customer experience, e-service satisfaction, website image, and engagement. Fourth, future researchers may use the customers' traits as an antecedent of e-servicescape and how different personality traits affect customer perception of e-servicescape. Fifth, future studies may observe the effect of online reviews in enhancing customers' trust and perceived value. Finally, future research may test the moderator role of other factors, such as customer demographic variables, individual cultural character, and personality traits.

\section{References}

Abarbanel, B., Bernhard, B., Singh, A. K., \& Lucas, A. (2015). Impact of virtual atmospherics and functional qualities on the online gambler's experience. Behaviour \& Information Technology, 34(10), 1005-1021. https://doi.org/10.1080/0144929X.2015.1046930

Agag, G. M., Khashan, M. A., Colmekcioglu, N., Almamy, A., Alharbi, N. S., Eid, R., ... Abdelmoety, Z. H. S. (2019). Converting hotels website visitors into buyers: How online hotel web assurance seals services decrease consumers' concerns and increase online booking intentions. Information Technology \& People, ITP-12-2017-0446. https://doi.org/10.1108/ITP-12-2017-0446

Agag, G., \& El-Masry, A. A. (2016a). Understanding consumer intention to participate in online travel community and effects on consumer intention to purchase travel online and WOM: An integration of innovation diffusion theory and TAM with trust. Computers in Human Behavior, 60, 97-111. https://doi.org/10.1016/j.chb.2016.02.038

Agag, G., \& El-Masry, A. A. (2016b). Understanding the determinants of hotel booking intentions and moderating role of habit. International Journal of Hospitality Management, 54, 52-67. https://doi.org/10.1016/j.ijhm.2016.01.007

Al-dweeri, R. M., Obeidat, Z. M., Al-dwiry, M. A., Alshurideh, M. T., \& Alhorani, A. M. (2017). The impact of e-service quality and e-loyalty on online shopping: Moderating effect of e-satisfaction and e-trust. International Journal of Marketing Studies, 9(2), 92-103. https://doi.org/10.5539/ijms.v9n2p92

Anderson, C. (2011). Search, OTAs, and online booking: An expanded analysis of the billboard effect. Cornell Hospitality Report, 11(8), 6-10. 
Anderson, J. C., \& Gerbing, D. W. (1988). Structural equation modeling in practice: A review and recommended two-step approach. Psychological Bulletin, 103(3), 411-423.

Andriani, P., Setyorini, N., \& Shibghatalloh, A. H. (2021). Investigating e-servicescape influence to customer response in digital islamic banking. International Journal of Islamic Economics and Finance (IJIEF), 4 (1), 101-120. https://doi.org/10.18196/ijief.v4i1.10299

Baki, R. (2020). Analysis of factors affecting customer trust in online hotel booking website usage. European Journal of Tourism, Hospitality and Recreation, 10(2), 106-117. https://doi.org/10.2478/ejthr-2020-0009

Ballantyne, D., \& Nilsson, E. (2017). All that is solid melts into air: The servicescape in digital service space. Journal of Services Marketing, 31(3), 226-235. https://doi.org/10.1108/JSM-03-2016-0115

Bitner, M. J. (1992). Servicescapes: The impact of physical surroundings on customers and employees. Journal of Marketing, 56(2), 57-71. https://doi.org/10.1177/002224299205600205

Boksberger, P. E., \& Melsen, L. (2011). Perceived value: A critical examination of definitions, concepts and measures for the service industry. Journal of Service Marketing, 25(3), 229-240. https://doi.org/10.1108/08876041111129209

Byrne, B. (2013). Structural equation modeling with EQS: Basic concepts, applications, and programming (2nd Eds.). New York: Routledge. https://doi.org/10.4324/9780203807644

Chan, I. C. C., Lam, L. W., Chow, C. W. C., Fong, L. H. N., \& Law, R. (2017). The effect of online reviews on hotel booking intention: The role of reader-reviewer similarity. International Journal of Hospitality Management, 66, 54-65. https://doi.org/10.1016/j.ijhm.2017.06.007

Chang, L. L. F., Backman, K., \& Chih Huang, Y. (2014). Creative tourism: A preliminary examination of creative tourists' motivation, experience, perceived value and revisit intention. International Journal of Culture, Tourism and Hospitality Research, 8(4), 401- 419. https://doi.org/10.1108/IJCTHR-04-2014-0032

Choi, H., \& Kandampully, J. (2019). The effect of atmosphere on customer engagement in upscale hotels: An application of S-O-R paradigm. International Journal of Hospitality Management, 77, 40-50 . https://doi.org/10.1016/j.ijhm.2018.06.012

Civelek, M. E. (2018). Essentials of structural equation modeling. Zea E-Books. https://doi.org/10.13014/K2SJ1HR5

Dai, B. (2007). The impact of online shopping experience on risk perceptions and online purchase intentions: the moderating role of product category and gender. Dissertation, University of Auburn.

Elbaz, A. M., Agag, G. M., \& Alkathiri, N. A. (2018). How ability, motivation and opportunity influence travel agents performance: The moderating role of absorptive capacity. Journal of Knowledge Management, 22(1), 119-141. https://doi.org/10.1108/JKM-07-2017-0308

Etikan, I. (2016). Comparison of convenience sampling and purposive sampling. American Journal of Theoretical and Applied Statistics, 5(1), 1-4. https://doi.org/10.11648/j.ajtas.20160501.11

Fishbein, M. (1979). A theory of reasoned action: Some applications and implications. Nebraska Symposium on Motivation, 27, 65-116.

Fornell, C., \& Larcker, D. (1981). Evaluating structural equation models with unobservable variables and measurement error. Journal of Marketing Research, 18(1), 39-50. https://10.1177/002224378101800104

Fu Tsang, N. K., Lai, M. T. H., \& Law, R. (2010). Measuring e-service quality for online travel agencies. Journal of Travel Tourism Marketing, 27(3), 306-323. https://doi.org/10.1080/10548401003744743

Gao, G. X., \& Bi, J. W. (2021). Hotel booking through online travel agency: Optimal stackelberg strategies under customer-centric payment service. Annals of Tourism Research, 86, 103074. https://doi.org/10.1016/j.annals.2020.103074

Hair, J. F., Black, W., Babin, B., \& Anderson, R. (2014). Multivariate data analysis (7. ed., Pearson new internat. ed). Pearson.

Harris, L. C., \& Goode, M. M. H. (2010). Online servicescapes, trust, and purchase intentions. Journal of Service Marketing, 24(3), 230-243. https://doi.org/10.1108/08876041011040631

Ho, C. I., \& Lee, Y. L. (2007). The development of an e-travel service quality scale. Tourism Management, 28(6), 1434-1449. https://doi.org/10.1016/j.tourman.2006.12.002 
Hopkins, C. D., Grove, S. J., Raymond, M. A., \& LaForge, M. C. (2009). Designing the e-Servicescape: Implications for online retailers. Journal of Internet Commerce, 8(1-2), 23-43. https://doi.org/10.1080/15332860903182487

Hoyle, R. H. (Ed.). (1995). Structural equation modeling: Concepts, issues, and applications. Sage Publications.

Huang, D., Li, Z., Mou, J., \& Liu, X. (2017). Effects of flow on young Chinese consumers' purchase intention: A study of e-servicescape in hotel booking context. Information Technology Tourism, 17(2), 203-228. https://doi.org/10.1007/s40558-016-0073-0

Ip, C., Law, R., \& Lee, H. (2011). A review of website evaluation studies in the tourism and hospitality fields from 1996 to 2009. International Journal of Tourism Resarch, 13(3), 234-265. https://doi.org/10.1002/jtr.815

Jackson, D. L. (2003). Revisiting sample size and number of parameter estimates: Some support for the n:q hypothesis. Structural Equation Model Multidiscip Journal, 10(1), 128-141. https://doi.org/10.1207/S15328007SEM1001_6

Jafarpour, S. H., \& Andalib, A. (2016). A new method for determination of effective criteria to evaluate electronic trust (E-trust) of online customers. Second International Conference on Web Resarch (ICWR), 54-59. https://doi.org/10.1109/ICWR.2016.7498446

Kahneman, D., \& Tversky, A. (1979). On the interpretation of intuitive probability: A reply to Jonathan Cohen. Cognition, 7(4), 409-411. https://doi.org/10.1016/0010-0277(79)90024-6

Kim, D. J., Ferrin, D. L., \& Rao, H. R. (2008). A trust-based consumer decision-making model in electronic commerce: The role of trust, perceived risk, and their antecedents. Decision Support System, 44(2), 544-564. https://doi.org/10.1016/j.dss.2007.07.001

Kim, H. W., Xu, Y., \& Gupta, S. (2012). Which is more important in Internet shopping, perceived price or trust? Electron Commerce Research Applications, 11(3), 241-252. https://doi.org/10.1016/j.elerap.2011.06.003

Kim, M. J., Chung, N., \& Lee, C. K. (2011). The effect of perceived trust on electronic commerce: Shopping online for tourism products and services in South Korea. Tourism Management, 32(2), 256-265. https://doi.org/10.1016/j.tourman.2010.01.011

Kim, S., Kim, J., \& Park, S. (2017). The effects of perceived value, website trust and hotel trust on online hotel booking intention. Sustainability, 9(12), 2262. https://doi.org/10.3390/su9122262

Kline, R. B. (2011). Principles and practice of structural equation modeling (3rd ed). Guilford Press.

Koernig, S. K. (2003). E-scapes: The electronic physical environment and service tangibility. Psychological Marketing, 20(2), 151-167. https://doi.org/10.1002/mar.10065

Koyuncu, C., \& Lien, D. (2003). E-commerce and consumer's purchasing behaviour. Applied Economics, 35(6), 721-726. https://doi.org/10.1080/0003684022000020850

Kühn, S. W., Spies, H., \& Petzer, D. J. (2019). Online servicescape dimensions as predictors of website trust in the South African domestic airline industry. Southern African Business Review, 19(1), 44-71. https://doi.org/10.25159/1998-8125/5833

Kurniawati, D. T., \&Yaakop, A. Y. (2021). The effect of e- servicescape dimensions on customer trust of tokopedia e-Store during Covid-19 pandemic. Jurnal Aplikasi Manajemen, 19(1), 1-10. https://doi.org/10.21776/ub.jam.2021.019.01.01

Lai, K. P., Chong, S. C., Ismail, H. B., \& Tong, D. Y. K. (2014). An explorative study of shopper-based salient e-servicescape attributes: A Means-End Chain approach. International Journal of Information Management, 34(4), 517-532. https://doi.org/10.1016/j.ijinfomgt.2014.01.010

Law, R. (2019). Evaluation of hotel websites: Progress and future developments (Invited paper for 'luminaries' special issue of international journal of hospitality management). International Journal of Hospitality Management, 76, 2-9. https://doi.org/10.1016/j.ijhm.2018.06.005

Law, R., Qi, S., \& Buhalis, D. (2010). Progress in tourism management: A review of website evaluation in tourism research. Tourism Management, 31(3), 297-313. https://doi.org/10.1016/j.tourman.2009.11.007

Lee, K. S., \& Tan, S. J. (2003). E-retailing versus physical retailing. Journal of Business Research, 11, 877-885. https://doi.org/10.1016/S0148-2963(01)002740 
Lee, S., \& Jeong, M. (2012). Effects of e-servicescape on consumers' flow experiences. Journal of Hospitality Tourism Technology, 3(1), 47-59. https://doi.org/10.1108/17579881211206534

Li, L., Peng, M., Jiang, N., \& Law, R. (2017). An empirical study on the influence of economy hotel website quality on online booking intentions. International Journal of Hospitality Management, 63, 1-10 . https://doi.org/10.1016/j.ijhm.2017.01.001

Ling, K. C., Chai, L. T., \& Piew, T. H. (2010). The effects of shopping orientations, online trust and prior online purchase experience toward customers' online purchase intention. International Business Research, 3(3), 63. https://doi.org/10.5539/ibr.v3n3p63

Malhotra, N. K., \& Dash, S. (2016). Marketing Research: An Applied Orientation (7th ed.) Pearson India Education Services.

Malik, G., \& Rao, A. S. (2019). Extended expectation-confirmation model to predict continued usage of ODR/ride hailing apps: Role of perceived value and self-efficacy. Information Technology Tourism, 21(4), 461-482. https://doi.org/10.1007/s40558-019-00152-3

Mehrabian, A., \& Russell, J. A. (1974). An Approach to Environment Psychology. MIT Press, Cambrigde. MA.

Nilsson, E., \& Ballantyne, D. (2014). Reexamining the place of servicescape in marketing: A service-dominant logic perspective. Journal of Service Marketing, 28(5), 374-379. https://doi.org/10.1108/JSM-01-2013-0004

O'brien, R. M. (2007). A caution regarding rules of thumb for variance inflation factors. Quality Quantity, 41(5), 673-690. https://doi.org/10.1007/s11135-006-9018-6

Pizam, A., \& Tasci, A. D. A. (2019). Experienscape: Expanding the concept of servicescape with a multi-stakeholder and multi-disciplinary approach (Invited paper for 'luminaries' special issue of international journal of hospitality management). International Journal of Hospitality Management, 76, 25-37. https://doi.org/10.1016/j.ijhm.2018.06.010

Ponte, E. B., Carvajal-Trujillo, E., \& Escobar-Rodríguez, T. (2015). Influence of trust and perceived value on the intention to purchase travel online: integrating the effects of assurance on trust antecedents. Tourism Management, 47(2), 286-302. https://doi.org/10.1016/j.tourman.2014.10.009

Rauyruen, P., Miller, K. E., \& Groth, M. (2009). B2B services: Linking service loyalty and brand equity. Journal of Service Marketing, 23(3), 175-186. https://doi.org/10.1108/IJBM-09-2016-0139

Sánchez-Pérez, M., Illescas-Manzano, M. D., \& Martínez-Puertas, S. (2020). You're the only one, or simply the best. Hotels differentiation, competition, agglomeration, and pricing. International Journal of Hospitality Management, 85, 102362. https://doi.org/10.1016/j.ijhm.2019.102362

Shafiq, R., Raza, R., \& Zia-ur-Rehman, M. (2011). Analysis of the factors affecting customers' purchase intention: The mediating role of perceived value. African Journal of Business Management, 5(26). https://doi.org/10.5897/AJBM10.1088

Soopramanien, D. (2011). Conflicting attitudes and scepticism towards online shopping: The role of experience: Online shopping attitudes. International Journal of Consumer Studies, 35(3), 338-347. https://doi.org/10.1111/j.1470-6431.2010.00945.x

Talwar, S., Dhir, A., Kaur, P., \& Mäntymäki, M. (2020). Why do people purchase from online travel agencies (Otas)? A consumption values perspective. International Journal of Hospitality Management, 88, 102534. https://doi.org/10.1016/j.ijhm.2020.102534

Tankovic, A. C., \& Benazic, D. (2018). The perception of e-servicescape and its influence on perceived e-shopping value and customer loyalty. Online Information Review, 42(7), 1124-1145. https://doi.org/10.1108/OIR-12-2016-0354

Tao, M., Nawaz, M. Z., Nawaz, S., Butt, A. H., \& Ahmad, H. (2018). Users' acceptance of innovative mobile hotel booking trends: UK vs. PRC. Information Technology Tourism, 20(1-4), 9-36. https://doi.org/10.1007/s40558-018-0123-x

Tatar, Ş. B., \& Eren-Erdoğmuş, İ. (2016). The effect of social media marketing on brand trust and brand loyalty for hotels. Information Technology Tourism, 16(3), 249-263. https://doi.org/10.1007/s40558-015-00486

Teng, H. J., Ni, J. J., \& Chen, H. H. (2018). Relationship between e-servicescape and purchase intention among heavy and light internet users. Internet Research, 28(2), 333-350.

https://doi.org/10.1108/IntR-10-2016-0303 
Toh, R. S., Raven, P., \& DeKay, F. (2011). Selling rooms: Hotels vs. third-party websites. Cornell Hospitality Quarterly, 52(2), 181-189. https://doi.org/10.1177/1938965511400409

Wang, L., Law, R., Guillet, B. D., Hung, K., \& Fong, D. K. C. (2015). Impact of hotel website quality on online booking intentions: E-Trust as a mediator. International Journal of Hospitality Management, 47, 108-115. https://doi.org/10.1016/j.ijhm.2015.03.012

Wu, J. F., \& Chang, Y. P. (2016). Multichannel integration quality, online perceived value and online purchase intention: A perspective of land-based retailers. Internet Research, 26(5), 1228-1248. https://doi.org/10.1108/IntR-04-2014-0111

Wu, W. Y., Phan, Q. P. T., \& Rivas, A. A. A. (2018). Correction to: How e-servicescapes affect customer online shopping intention: the moderating effects of gender and online purchasing experience. Information System E-Business Management, 16(2), 477-477. https://doi.org/10.1007/s10257-018-0370-6

Yadav, R., \& Mahara, T. (2020). Exploring the role of e-servicescape dimensions on customer online shopping: A stimulus-organism-response paradigm. Journal of Electron Commerce in Organizations, 18(3), 53-73. https://doi.org/10.4018/JECO.2020070104

Yang, Y., \& Leung, X. Y. (2018). A better last-minute hotel deal via app? Cross-channel price disparities between Hotel Tonight and OTAs. Tourism Management, 68, 198-209.

https://doi.org/10.1016/j.tourman.2018.03.016

\section{Appendix A. The dropped items}

\begin{tabular}{cl}
\hline Construct & \multicolumn{1}{c}{ Items } \\
\hline & I like the way this web site looks \\
The website is unadventurous \\
The website is not easily navigated \\
This web site is difficult to use \\
There is a great deal of irrelevant information \\
If I wanted to, I could customize this web site to what I like (e.g. changing colors, layout, \\
fonts, etc.) \\
When communicating with this web site I am rarely addressed using my correct name \\
This web site helps me to compare products and prices \\
I feel that this is not a very engaging web site \\
Paying for goods is straightforward \\
Overall, this web site seems security conscious \\
Considering the effort, I make in booking on this website, online booking here is \\
werthwhile \\
Overall, online booking on this website delivers me good value
\end{tabular}

\section{Copyrights}

Copyright for this article is retained by the author(s), with first publication rights granted to the journal.

This is an open-access article distributed under the terms and conditions of the Creative Commons Attribution license (http://creativecommons.org/licenses/by/4.0/). 